\title{
Biosafety measures to prevent COVID-19 in healthcare professionals: an integrative review
}

\author{
Medidas de biossegurança para prevenção da Covid-19 em profissionais de saúde: revisão integrativa \\ Medidas de bioseguridad para prevenir el COVID-19 en profesionales de la salud: una revisión integradora
}

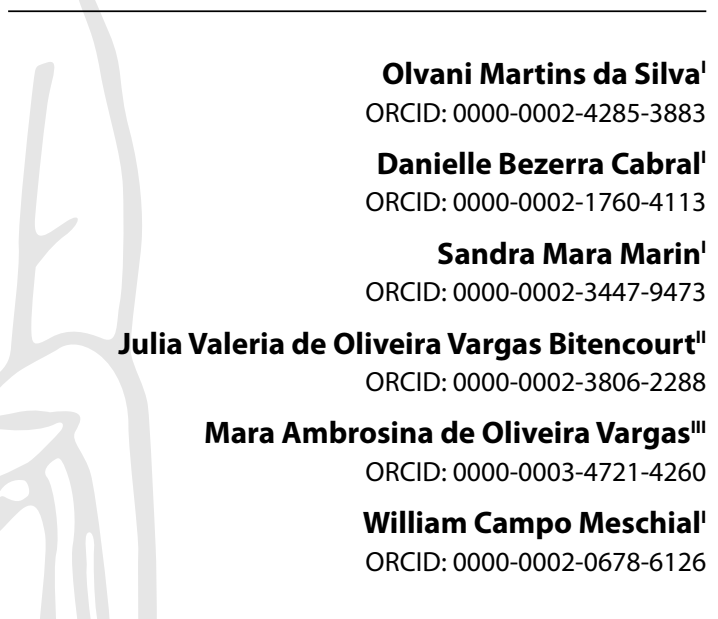

'Universidade do Estado de Santa Catarina. Chapecó, Santa Catarina, Brazil.

"Universidade Federal da Fronteira Sul. Chapecó, Santa Catarina, Brazil.

"'Universidade Federal de Santa Catarina. Florianópolis, Santa Catarina, Brazil.

How to cite this article: Silva OM, Cabral DB, Marin SM, Bitencourt JVOV, Vargas MAO, Meschial WC. Biosafety measures to prevent COVID-19 in healthcare professionals: an integrative review. Rev Bras Enferm. 2022;75(1):e20201191. https://doi.org/10.1590/0034-7167-2020-1191

\section{Corresponding author: William Campo Meschial E-mail: william.meschial@udesc.br}

EDITOR IN CHIEF: Dulce Barbosa ASSOCIATE EDITOR: Fátima Helena Espírito Santo

Submission: 05-05-2020

Approval: 04-18-2021

\section{ABSTRACT}

Objective: to identify the main biosafety measures for preventing COVID-19 in healthcare professionals. Methods: this is an integrative literature review, with studies published between January and July 2020, on the MEDLINE/PubMed, Scopus, Embase, Web of Science, LILACS, SciELo, Wiley Online Library, Cochrane CINAHL databases. The selection of studies followed the PRISMA recommendations. Results: among the 2,208 publications identified, 12 studies comprised the sample, which enabled the analysis in four thematic categories: The importance of using recommendations about the use of personal protective equipment; The restructuring of new operational and clinical routines and flows in the practice of services; Monitoring professionals, especially testing; Conducting training. Conclusions: the phenomena involved are innumerable, covering operational management and the training of teams to deal with highly infectious pathogens and disease outbreaks.

Descriptors: Containment of Biohazards; COVID-19; Personal Protective Equipment; Health Personnel; Hospital Services.

\section{RESUMO}

Objetivo: identificar as principais medidas de biossegurança para prevenção da COVID-19 em profissionais de saúde. Métodos: revisão integrativa da literatura, com estudos publicados entre janeiro e julho de 2020, nas bases de dados MEDLINE/PubMed, Scopus, Embase, Web of Science, LILACS, SciELo, Wiley Online Library, Cochrane CINAHL. A seleção dos estudos seguiu as recomendações da diretriz PRISMA. Resultados: dentre as 2.208 publicações identificadas, 12 estudos compuseram a amostra, os quais possibilitaram a análise em quatro categorias temáticas: $A$ importância do emprego das recomendações acerca do uso dos equipamentos de proteção individual; A reestruturação de novas rotinas e fluxos operacionais e clínicos na prática dos serviços; A realização de monitoramento dos profissionais, em especial a testagem; A realização de treinamentos. Conclusões: os fenômenos envolvidos são inúmeros, abrangendo a gestão operacional e a capacitação das equipes para lidarem com patógenos altamente infecciosos e situações de surtos de doenças.

Descritores: Contenção de Riscos Biológicos; Infecções por Coronavírus; Equipamento de Proteção Individual; Pessoal de Saúde; Serviços Hospitalares.

\section{RESUMEN}

Objetivo: identificar las principales medidas de bioseguridad para la prevención de COVID-19 en profesionales de la salud. Métodos: revisión integradora de la literatura, con estudios publicados entre enero y julio de 2020, en las bases de datos MEDLINE/PubMed, Scopus, Embase, Web of Science, LILACS, SciELo, Wiley Online Library, Cochrane CINAHL. La selección de los estudios siguió las recomendaciones de la guía PRISMA. Resultados: de las 2.208 publicaciones identificadas, 12 estudios conformaron la muestra, lo que permitió el análisis en cuatro categorías temáticas: la importancia de utilizar recomendaciones sobre el uso de equipos de protección personal; La reestructuración de nuevas rutinas y flujos operativos $y$ clínicos en la práctica de los servicios; Monitoreo de profesionales, especialmente pruebas; Realización de formación. Conclusiones: los fenómenos involucrados son innumerables, abarcando la gestión operativa y la capacitación de equipos para enfrentar patógenos altamente infecciosos y brotes de enfermedades.

Descriptores: Contención de Riesgos Biológicos; Infecciones por Coronavirus; Equipo de Protección Personal; Personal de Salud; Servicios Hospitalarios. 


\section{INTRODUCTION}

The COVID-19 pandemic is a latent threat to public health in the world that has grown exponentially and has spread rapidly, remaining surrounded by questions and uncertainties, such as the emergence of new mutations. Several countries have been affected in different ways, however there are three defining characteristics that are similar: 1 ) speed and scale - rapid spread with the potential to overwhelm even the most structured health systems; 2 ) severity - about $20 \%$ of cases are severe or critical, with an increased risk of severe complications in older age groups and those with certain underlying conditions; 3 ) social and economic disruption - destabilization in the health care system and the need for measures to control transmission, with wide and deep socioeconomic consequences ${ }^{(1-2)}$.

Against this background, the World Health Organization (WHO) published the Pandemic Preparedness and Response Plan (PPRP). The PPRP has established three objectives to combat the spread and limit the damage caused by the disease. First, at the global level, it outlined steps for international coordination to quickly support countries to plan, finance and implement their response. To this end, countries must demand from the authorities: real-time information on the evolution of epidemiology and risks; timely access to essential supplies, medicines and equipment; access and training in recent technical guidelines and best practices. In its second objective, also at the international level, the PPRP defined the necessary steps for a global transparent process, with research and innovation as priorities, aiming to guarantee the equitable availability of therapeutic, diagnostic and vaccine measures. These two initiatives are in line with the third objective, which is to increase the status of preparedness and responses of countries in the face of COVID-19(1).

In this sense, working groups linked to governmental organizations, professional and academic associations have worked on the subject on a daily basis, in order to identify, discuss and deliberate strategies to control this serious problem. The new setting influences health and safety of professionals involved in care to population and increases social and professional concern about the need to reassess actions for prevention of COVID-19, among workers exposed to virus, during their work activities, at different levels of health care. It is important to investigate and discuss biosafety measures regarding the potential risk of contamination of these professionals ${ }^{(3)}$.

COVID-19 is transmitted, from person to person, through respiratory droplets expelled during speech, coughing or sneezing, by direct contact with other people in crowded places, or surfaces contaminated with the SARS-CoV-2 virus and also by procedures that generate aerosols ${ }^{(4)}$. Thus, it is necessary to use the appropriate Personal Protective Equipment (PPE) to avoid contamination. Concomitant with the provision of PPE, health services need to adopt control actions in the spread of the virus, such as structural adjustments and in operational and clinical flows, monitoring professionals and conducting continuous training, in addition to constant encouragement to rigorous hand hygiene, maintenance of adequate workplaces, with good hygiene and reduction of strenuous working hours for healthcare professionals, which can increase the risk of contamination ${ }^{(5)}$.
In Brazil, ANVISA recommends, among the biosafety measures, to train professionals for the task of identifying potentially dangerous situations, such as failures in biosafety procedures, in the correct attire and unattire, to avoid adverse effects of use, such as time-related skin complications of use, which can generate inappropriate use of PPE, with consequent contamination. It is also recommended to properly dispose of all PPE after care for patients suspected or confirmed COVID-19 $9^{(4-5)}$.

In this sense, the present study is justified by the need to discuss the adoption of biosafety measures in health services, in order to mitigate the risks of exposure and contamination by SARS-CoV- 2 in professionals. Services have many challenges to develop these actions. Therefore, it is relevant to obtain scientific evidence that responds to how prevention and control measures are being developed on the world stage, seeking to provide subsidies to managers and healthcare professionals in the fight against COVID-19.

\section{OBJECTIVE}

To identify the main biosafety measures for preventing COVID-19 in healthcare professionals.

\section{METHODS}

This is an integrative literature review (ILR), developed according to the methodological approach proposed by Whittemore and Knafl ${ }^{(6)}$, adopting the PRISMA (Preferred Reporting Items for Systematic Reviews and Meta-Analyzes) recommendations ${ }^{(7)}$. In ILR, we seek to aggregate synthesis and analysis of various perspectives on a particular phenomenon or health problem based on an orderly and systematic survey of published studies. Therefore, there is a potential for producing evidence for professional practice in health and nursing. In this study, the following steps were carried out: research question elaboration (identification of the problem), search for primary studies, evaluation of studies by the inclusion and exclusion criteria, analysis of data from primary studies and review presentation ${ }^{(6)}$.

The research question was elaborated, using the Population Interest Context (PICo) strategy ${ }^{(8)}$ : healthcare professionals (P population), biosafety measures (I- phenomenon of interest), the COVID-19 pandemic (Co - context). Thus, the following question was raised: what are the main biosafety measures being structured by health services to protect COVID-19 healthcare professionals?

The search for primary studies was carried out during the month of July 2020 through the Federated Academic Community (CAFe - Comunidade Acadêmica Federada), selecting the educational institution in which the researchers are linked, which was accessed through the CAPES Journal Portal. The electronic databases MEDLINE/PubMed (Science Direct and US National Library of Medicine), Scopus, Embase, Web of Science, Latin American and Caribbean Literature in Health Sciences (LILACS), Scientific Eletronic Library Online (SciELo) were selected, Wiley Online Library, Cochrane Library and Cumulative Index to Nursing and Allied Health Literature (CINAHL).

The Health Sciences Descriptors (DECs), "Health Personnel”, "Biological Hazard Containment","Personal Protective Equipment" 
and "Coronavirus Infections", were used for the electronic database LILACS and SciELo; the Medical Subject Headings (MeSH) "Health personnel”, “Containment of Biohazards", "Personal Protective Equipment", "Coronavirus Infections" were used for the other bases. Synonyms/entry terms and uncontrolled descriptors were used, based on the most used word mapping in titles and abstracts of publications on the subject of interest, and the Boolean operators AND and OR were used to perform the combination of descriptors. A search strategy was developed for PubMed/MEDLINE, which was adapted for the other databases, considering its particularities (Chart 1).

Chart 1 - Search strategy designed for PubMed/MEDLINE, Brazil, 2020

((“Health personnel” OR "Personnel, Health" OR "Health Care Providers" OR "Health Care Provider" OR "Provider, Health Care" OR "Providers, Health Care" OR "Healthcare Providers" OR "Healthcare Provider" OR "Provider, Healthcare" OR "Providers, Healthcare" OR "Healthcare Workers" OR "Healthcare Worker" OR "Healthcare professionals" OR "Healthcare professionals") AND ("Containment of Biohazards" OR "Biohazard Containment" OR "Containment, Biohazard" OR "Biohazards Containment" OR "Containment, Biohazards" OR "Containment, Biologic" OR "Biologic Containment" OR "Biological Containment" OR "Containment, Biological" OR "Biosafety" OR "Physical Containment" OR "Containment, Physical" OR "Risk Management" OR "Personal Protective Equipment" OR "Equipment, Personal Protective" OR "Protective Equipment, Personal" OR "Individual protection equipment")) AND ("Coronavirus Infections" OR "COVID-19" OR "2019 novel coronavirus disease" OR "COVID-19" OR "COVID-19 pandemic" OR "SARS-CoV-2 infection" OR "COVID-19 virus disease" OR "2019 novel coronavirus infection" OR "2019-nCoV infection" OR "coronavirus disease 2019" OR "coronavirus disease-19" OR "2019-nCoV disease" OR "COVID-19 virus infection")

For the eligibility of studies, primary studies that addressed biosafety measures directed at COVID-19 for the protection of healthcare professionals, published in English, Spanish and Portuguese, available in full, from January to July 2020, considering the recent emergence of COVID-19. were included Duplicate studies, review articles, editorials, book chapters, guidelines and other texts that did not fit the study's theme were excluded. Studies conducted in specific settings, such as laboratories and dental services, were also excluded. The search process and study selection were carried out by two researchers, simultaneously. In cases of divergence, a consensus was sought with the other researchers involved in the study. The flowchart presented below describes the article selection process.

The analysis stage started with the translation, reading and interpretation of results. The article was characterized based on the extraction of title, country in which the study was carried out, year, language, database and objective. Afterwards, material and method synthesis was carried out, as well as the main results and recommendations of the authors.

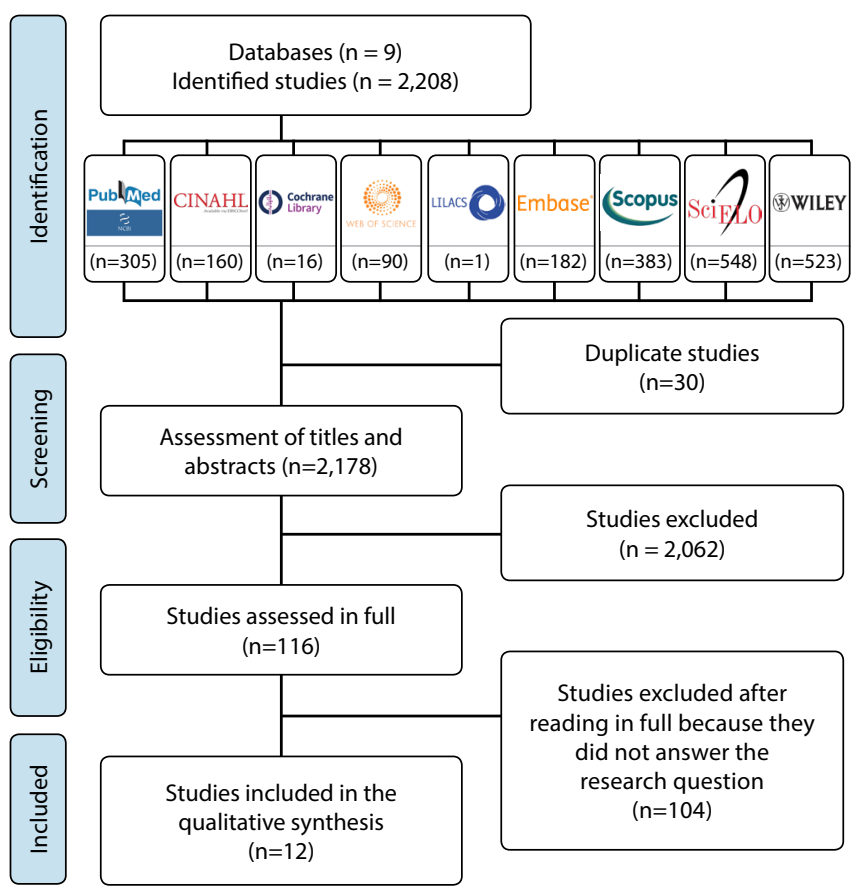

Source: Moher et al. (2009) (7), adapted.

Figure 1 - Flowchart of the selection of articles for the integrative review, elaborated from the PRISMA recommendation, $2020^{(7)}$

In the review presentation, the results were descriptively presented, interpreted in categories and discussed based on the literature related to the theme of the study. As this is an ILR, the research was not submitted to an Institutional Review Board, but the authors'ideas were respected, as recommended by the copyright law.

\section{RESULTS}

In this ILR, 12 original articles were included, which met the established criteria. Synthesis of the scientific production evaluated is distributed in Chart 2. All studies were published in 2020, with the majority of publications coming from Asia, followed by Europe and America. The main settings investigated were Intensive Care Units (ICU) and emergency room, targeting healthcare professionals and patients. The methodological approach used relied mainly on the development of observational studies.

Chart 2 - Characterization and main results of articles included in the integrative review in order of selection, Brazil, 2020

\begin{tabular}{|c|c|c|c|}
\hline Author/Year/Country & Title & Objective/Design & Main results/Conclusions \\
\hline $\begin{array}{l}\text { Christensen L, } \\
\text { Rasmussen CS, } \\
\text { Benfield T, Franc JM(9) } \\
2020 \\
\text { Denmark }\end{array}$ & $\begin{array}{l}\text { A Randomized Trial of } \\
\text { Instructor-Led Training } \\
\text { Versus Video Lesson in } \\
\text { Training Health Care } \\
\text { Providers in Proper Donning } \\
\text { and Doffing of Personal } \\
\text { Protective Equipment }\end{array}$ & $\begin{array}{l}\text { Compare instructor-led } \\
\text { training with video-based } \\
\text { instruction on donning and } \\
\text { doffing PPE. Randomized } \\
\text { Clinical Trial (pilot study). }\end{array}$ & $\begin{array}{l}\text { The average score for correct attire and unattire was } 84.8 / 100 \text { and } \\
79.1 / 100 \text { for the instructor-led group and } 88 / 100 \text { and } 73.9 / 100 \\
\text { for the video group. There was no significant difference in scores } \\
\text { between classes taught by instructor and video. Video training } \\
\text { proved to be a fast and efficient method in terms of resources for } \\
\text { training in response to the COVID-19 pandemic. }\end{array}$ \\
\hline
\end{tabular}




\begin{tabular}{|c|c|c|c|}
\hline Author/Year/Country & Title & Objective/Design & Main results/Conclusions \\
\hline $\begin{array}{l}\text { Díaz-Guio DA, Ricardo- } \\
\text { Zapata A, Ospina-Velez } \\
\text { J, Gómes-Candamil } \\
\text { G, Mora-Martinez S, } \\
\text { Rodriguez-Morales A } \text { A }^{(10)} \\
2020 \\
\text { Colombia }\end{array}$ & $\begin{array}{l}\text { Cognitive load and } \\
\text { performance of health care } \\
\text { professional in donning } \\
\text { and doffing PPE before and } \\
\text { after a simulation-based } \\
\text { educational intervention } \\
\text { and its implications during } \\
\text { the COVID-19 pandemic for } \\
\text { biosafety }\end{array}$ & $\begin{array}{l}\text { Assess the cognitive load } \\
\text { and the performance of } \\
\text { healthcare professionals } \\
\text { in PPE donning and } \\
\text { doffing before and after a } \\
\text { simulation-based educational } \\
\text { intervention. Quasi- } \\
\text { experimental study. }\end{array}$ & $\begin{array}{l}\text { In the pre-test, all participants failed to don and doff PPE, } 98.4 \% \\
\text { were contaminated. In the post-test, } 100 \% \text { were successful in } \\
\text { donning PPE and } 94.8 \% \text { in doffing it; only } 9.8 \% \text { were contaminated. } \\
\text { The greatest difficulties reported were in doffing the apron and } \\
\text { the N95 mask. In response to the current COVID-19 pandemic, } \\
\text { training activities in PPE donning and doffing provide a means of } \\
\text { training personnel, reducing the cognitive burden and the risk of } \\
\text { contamination of professionals. }\end{array}$ \\
\hline $\begin{array}{l}\text { Wee LE, Fua TP, Chua } \\
\text { YY, Ho AFW, Sim XYJ, } \\
\text { Conceicao EP, et al }\left.\right|^{(11)} \\
2020 \\
\text { Singapore }\end{array}$ & $\begin{array}{l}\text { Containing COVID-19 in the } \\
\text { emergency department: } \\
\text { the role of improved case } \\
\text { detection and segregation } \\
\text { of suspect cases }\end{array}$ & $\begin{array}{l}\text { Assess the impact of a } \\
\text { strategy on case detection, } \\
\text { resource utilization and } \\
\text { infection control, related to } \\
\text { COVID-19. Observational } \\
\text { study. }\end{array}$ & $\begin{array}{l}\text { Most patients with respiratory syndrome }(84.2 \%, 59 / 70) \text { were } \\
\text { detected in emergency screening, because they met the criteria } \\
\text { for a suspected case. Of these, } 34 \text { met the official selection criteria; } \\
\text { another } 25 \text { were detected by the broader internal screening criteria. } \\
\text { There were no cases of nosocomial transmission of exposure in the } \\
\text { emergency department. }\end{array}$ \\
\hline $\begin{array}{l}\text { Wee LE, Sim XYJ, } \\
\text { Conceicao EP, Tan } \\
\text { BH, Venkatachalam I, } \\
\text { LingML }{ }^{(12)} \\
2020 \\
\text { Singapore }\end{array}$ & $\begin{array}{l}\text { Containing COVID-19 } \\
\text { outside the isolation } \\
\text { ward: the impact of an } \\
\text { infection control bundle } \\
\text { on environmental } \\
\text { contamination and } \\
\text { transmission in a cohorted } \\
\text { general Ward }\end{array}$ & $\begin{array}{l}\text { To evaluate the impact of an } \\
\text { infection control package } \\
\text { on contamination and } \\
\text { environmental transmission } \\
\text { and transmission in a } \\
\text { cohorted general cohort, with } \\
\text { suspected cases of COVID-19. } \\
\text { Observational study. }\end{array}$ & $\begin{array}{l}\text { Sampling from the patients' environment was positive for SARS- } \\
\text { CoV- } 2 \text { in } 5 \text { of the } 28 \text { cases; in patients who needed supplemental } \\
\text { oxygen, there was a greater chance of environmental } \\
\text { contamination. Only } 3 \text { healthcare professionals (1.2\%) required } \\
\text { quarantine. No transmission from patient to healthcare professional } \\
\text { has been documented. The implementation of an intervention } \\
\text { package to mitigate the transmission of COVID-19 in the studied } \\
\text { setting proved to be effective. }\end{array}$ \\
\hline $\begin{array}{l}\text { Evans HL, Thomas } \\
\text { CS, Bell LH, Hink AB, } \\
\text { O'Driscoll S, Tobin CT } \\
\text { et al }{ }^{(13)} \\
2020 \\
\text { USA }\end{array}$ & $\begin{array}{l}\text { Development of a Sterile } \\
\text { Personal Protective } \\
\text { Equipment Donning and } \\
\text { Doffing Procedure to } \\
\text { Protect Surgical Teams } \\
\text { from SARS-CoV-2 Exposure } \\
\text { during the COVID-19 } \\
\text { Pandemic. }\end{array}$ & $\begin{array}{l}\text { Develop a standardized } \\
\text { protocol regarding the } \\
\text { placement and donning } \\
\text { and doffing sterile PPE in a } \\
\text { surgical environment during } \\
\text { COVID-19. Observational } \\
\text { study. }\end{array}$ & $\begin{array}{l}\text { The procedures for donning and doffing PPE were printed and } \\
\text { attached in the operating rooms and procedure areas. These } \\
\text { procedures provided the team of professionals with the first } \\
\text { specific education in a sterile environment for PPE donning and } \\
\text { doffing. The presence of a dofficer proved to be important to } \\
\text { prevent these deviations and potential contamination events in } \\
\text { donning/doffing. }\end{array}$ \\
\hline $\begin{array}{l}\text { Reusken CB, Buiting } \\
\text { A, Bleeker-Rovers C, } \\
\text { Diederen B, Hooiveld } \\
\text { M, Friesema H, et al }{ }^{(14)} \\
2020 \\
\text { The Netherlands }\end{array}$ & $\begin{array}{l}\text { Rapid assessment of } \\
\text { regional SARS-CoV-2 } \\
\text { community transmission } \\
\text { through a convenience } \\
\text { sample of healthcare } \\
\text { workers, the Netherlands, } \\
\text { March } 2020\end{array}$ & $\begin{array}{l}\text { To evaluate community } \\
\text { transmission in Noord- } \\
\text { Brabant, the Netherlands, in } \\
\text { healthcare professionals with } \\
\text { mild respiratory complaints } \\
\text { and without an SARS- } \\
\text { CoV-2 epidemiological link. } \\
\text { Observational study. }\end{array}$ & $\begin{array}{l}\text { Healthcare professionals with mild respiratory complaints and } \\
\text { no epidemiological link were tested for SARS-CoV- } 2 \text {. Of 1,097 } \\
\text { professionals tested in } 9 \text { hospitals, } 45 \text { ( } 4.1 \% \text { ) were positive. Of } \\
\text { the six hospitals with contaminated professionals, two were } \\
\text { responsible for } 38 \text { professionals. The results suggest transmission } \\
\text { in the community unnoticed, with a potential risk of nosocomial } \\
\text { transmission. }\end{array}$ \\
\hline $\begin{array}{l}\text { Fregene TE, Nadarajah } \\
\text { P, Buckley JF, Bigham S, } \\
\text { NangaliaV(15)2020 } \\
\text { United Kingdom }\end{array}$ & $\begin{array}{l}\text { Use of in situ simulation to } \\
\text { evaluate the operational } \\
\text { readiness of a high- } \\
\text { consequence infectious } \\
\text { disease intensive care unit }\end{array}$ & $\begin{array}{l}\text { Identify potential problems, } \\
\text { test the robustness of the } \\
\text { systems and inform the } \\
\text { modification of standard } \\
\text { operating procedures for } \\
\text { a patient with COVID-19 } \\
\text { admitted to an ICU. } \\
\text { Observational study. }\end{array}$ & $\begin{array}{l}\text { The simulations revealed several important latent risks and made } \\
\text { it possible to implement corrective measures before the admission } \\
\text { of patients with COVID-19. In-situ simulation is recommended for } \\
\text { teams working in sectors that must receive patients with COVID-19, } \\
\text { in order to detect their own unique risks and assist in the creation } \\
\text { of local guidelines. }\end{array}$ \\
\hline $\begin{array}{l}\text { Min L, Shou-Zhen C, } \\
\text { Ke-Wei X, Yang Y, Qing- } \\
\text { Tang Z, Hui Z, et al }{ }^{(16)} \\
2020 \\
\text { China }\end{array}$ & $\begin{array}{l}\text { Use of personal protective } \\
\text { equipment against } \\
\text { coronavirus disease } 2019 \\
\text { by healthcare professionals } \\
\text { in Wuhan, China: cross } \\
\text { sectional study }\end{array}$ & $\begin{array}{l}\text { Examine the protective } \\
\text { effects of personal protective } \\
\text { equipment suitable for } \\
\text { healthcare professionals } \\
\text { who care for patients with } \\
\text { COVID-19. Observational } \\
\text { study. }\end{array}$ & $\begin{array}{l}\text { All } 420 \text { study participants had direct contact with patients with } \\
\text { COVID-19 and underwent at least one aerosol-generating } \\
\text { procedure. No participant reported symptoms related to COVID-19, } \\
\text { all tests being negative for SARS-CoV-2 and lgM or IgG antibodies. } \\
\text { Despite the high risk of exposure, professionals were adequately } \\
\text { protected. Health systems must prioritize the acquisition and } \\
\text { distribution of PPE and provide adequate training in its use. }\end{array}$ \\
\hline $\begin{array}{l}\text { Tan W, Ye Y, Yang Y, } \\
\text { Chen Z, Yang X, Zhu C, } \\
\text { et al (17) } \\
2020 \\
\text { China }\end{array}$ & $\begin{array}{l}\text { Whole-Process Emergency } \\
\text { Training of Personal } \\
\text { Protective Equipment Helps } \\
\text { Healthcare Workers Against } \\
\text { COVID-19 } \\
\text { Design and Effect }\end{array}$ & $\begin{array}{l}\text { Develop an emergency } \\
\text { PPE training program for } \\
\text { healthcare professionals } \\
\text { under the threat of COVID-19 } \\
\text { and evaluate the effect of the } \\
\text { program. Quasi-experimental } \\
\text { study. }\end{array}$ & $\begin{array}{l}\text { The scores of post-test were significantly better when compared } \\
\text { to those of pre-test. Among all the PPE, the N95 respirator and the } \\
\text { apron needed more training. This training program significantly } \\
\text { improved the performance of participants. }\end{array}$ \\
\hline
\end{tabular}




\begin{tabular}{|c|c|c|c|}
\hline Author/Year/Country & Title & Objective/Design & Main results/Conclusions \\
\hline $\begin{array}{l}\text { Jin YH, Huang Q, Wang } \\
\text { YY, Zeng XT, Luo LS, } \\
\text { Pan ZY(18) } \\
2020 \\
\text { China }\end{array}$ & $\begin{array}{l}\text { Perceived infection } \\
\text { transmission routes, } \\
\text { infection control practices, } \\
\text { psychosocial changes, and } \\
\text { management of COVID-19 } \\
\text { infected healthcare workers } \\
\text { in a tertiary acute care } \\
\text { hospital in Wuhan: a cross- } \\
\text { sectional survey }\end{array}$ & $\begin{array}{l}\text { Explore the route of SARS- } \\
\text { CoV- } 2 \text { infection, the influence } \\
\text { and management procedures } \\
\text { of healthcare professionals. } \\
\text { Observational study. }\end{array}$ & $\begin{array}{l}\text { Among the } 103 \text { professionals included in the study, } 87 \text { ( } 84.5 \%) \\
\text { thought they were infected in the hospital work environment. } \\
\text { Swab collection and physical examination were the procedures } \\
\text { considered to be the most likely to cause infection by nurses and } \\
\text { doctors, respectively. Forty-three ( } 41.8 \% \text { ) considered the infection } \\
\text { related to the use of common PPE (masks and gloves). The main } \\
\text { mode of transmission perceived was not to maintain protection } \\
\text { when working at a short distance and to have contact with infected } \\
\text { cases. }\end{array}$ \\
\hline $\begin{array}{l}\text { Razzini K, Castrica M, } \\
\text { Menchetti L, Maggi L, } \\
\text { Negroni L, Orfeo NV, } \\
\text { et al }{ }^{(19)} \\
2020 \\
\text { Italy }\end{array}$ & $\begin{array}{l}\text { SARS-CoV-2 RNA detection } \\
\text { in the air and on surfaces } \\
\text { in the COVID-19 ward of a } \\
\text { hospital in Milan, Italy }\end{array}$ & $\begin{array}{l}\text { To evaluate the } \\
\text { contamination of air and } \\
\text { surfaces by SARS-CoV-2 RNA } \\
\text { in the COVID-19 ward of an } \\
\text { Italian hospital. Observational } \\
\text { study. }\end{array}$ & $\begin{array}{l}\text { Overall, } 24.3 \% \text { of the smear samples were positive, but none of } \\
\text { them were collected in clean areas. The rate of positivity was higher } \\
\text { in the contaminated ( } 35.0 \%) \text { and semi-contaminated ( } 50.0 \%) \text { areas. } \\
\text { The most contaminated surfaces were hand sanitizer dispensers } \\
(100.0 \%) \text {, medical equipment }(50.0 \%) \text {, touch screens }(50.0 \%) \text {, } \\
\text { shelves ( } 40.0 \%) \text {, protective grids ( } 33.3 \%) \text { and door handles }(25.0 \%) \text {. } \\
\text { All air samples collected in the contaminated area were positive, } \\
\text { while the viral RNA was not detected in semi-contaminated or } \\
\text { clean areas. The results show the need for rigorous disinfection, } \\
\text { hand hygiene and the need for airborne isolation precautions. }\end{array}$ \\
\hline $\begin{array}{l}\text { Rivett L, Sridhar S, } \\
\text { Sparkes D, Routledge } \\
\text { M, Jones NK, Forrest S, } \\
\text { et al(20) } \\
2020 \\
\text { United Kingdom }\end{array}$ & $\begin{array}{l}\text { Screening of healthcare } \\
\text { workers for SARS-CoV-2 } \\
\text { highlights the role of } \\
\text { asymptomatic carriage in } \\
\text { COVID-19 transmission }\end{array}$ & $\begin{array}{l}\text { Present the initial findings of } \\
\text { a comprehensive employee } \\
\text { screening program at the } \\
\text { Cambridge University } \\
\text { Hospitals NHS Foundation } \\
\text { Trust. Observational study. }\end{array}$ & $\begin{array}{l}\text { Among asymptomatic professionals, } 3 \% \text { tested positive for SARS- } \\
\text { CoV-2. } 12 / 30(40 \%) \text { had symptoms compatible with COVID- } 19>7 \\
\text { days before the test. The results demonstrate the usefulness of a } \\
\text { comprehensive screening of healthcare professionals with minimal } \\
\text { symptoms or asymptomatic. This approach is critical for protecting } \\
\text { patients and healthcare professionals. }\end{array}$ \\
\hline
\end{tabular}

The recommendations of the main biosafety measures for preventing COVID-19 in healthcare professionals are presented below, structured in four categories.

\section{Personal Protective Equipment}

It became evident that the main form of contagion of COVID-19 to healthcare professionals was the inappropriate use of PPE in their workplaces ${ }^{(18)}$. This fact motivated the search to evaluate the effectiveness of PPE protection, in addition to the importance of using the attire and unattire checklist ${ }^{(15)}$.

The main mode of transmission is breaking the protective barrier $^{(18)}$, so that the correct use of masks, caps, gloves, protective clothing/aprons, disposable shoe cover, goggles or face shield protects professionals exposed to the risks of COVID-19 ${ }^{(16)}$. In this sense, to reduce the likelihood of nosocomial transmission and continuous surveillance on the front lines of professionals, a stratified risk approach was adopted in relation to $\mathrm{PPE}^{(11-12)}$, as a complete equipping of PPE for any procedures that generate aerosol or not ${ }^{(11-12)}$, mandatory use of PFF2 respirator or similar in the emergency room, regardless of symptomatic or asymptomatic patient and respirator storage after use in a closed container ${ }^{(11)}$.

Another important element in the use of PPE refers to the monitoring of quality and comfort during its use, as some masks restrict interlocutors opening their mouth, muffling speech, and the visors hinder the view ${ }^{(15)}$. Moreover, it is necessary to follow the step by step of donning and doffing PPE, to know the variability of the techniques of this procedure, avoiding contamination and body exposure ${ }^{(13)}$.

\section{Reorganization of flows and routines}

In this category, evidence is presented of how important the previous structural study of the units that will receive patients with COVID-19 is. Simulations carried out detected, in ICU environments, latent risks, equipment failures, electrical problems, passage flows and inadequate transport, which made it possible to formulate corrective measures ${ }^{(15)}$.

Structural changes, such as expanding environments, readjusting the flow of traffic to patients, adopting broad criteria for screening symptomatic or suspicious individuals, segregating those with respiratory symptoms, rooms with negative pressure when aerosol-generating procedures in confirmed COVID-19 patients, intensification of environmental and hand hygiene ${ }^{(12)}$ and air conditioning system with negative pressure ${ }^{(19)}$, were some of the measures adopted by the institutions.

Posters were also used on the procedure for donning and doffing PPE, diagrams, flowcharts, photos of simulation of the procedures for donning and doffing PPE posted in procedure areas, to facilitate viewing ${ }^{(13)}$. Development of checklist ${ }^{(13,15)}$ on Google Doc platform, photographs corresponding to each stage of the checklist and protocols reviewed by specialists were also signaled in studies ${ }^{(13)}$.

\section{Monitoring of healthcare professionals}

In this category, it was evidenced that studies consider symptoms such as cough, dyspnea, reported twice a day, as well as measuring body temperature for screening suspected cases. Tests, such as nasopharyngeal swabs and IgG and IgM serological tests, were also used, with molecular testing of real-time reverse transcriptase polymerase chain reaction (RT-PCR) considered as the gold standard test for diagnosing the disease in professionals ${ }^{(14,16)}$.

The use of comprehensive screening for the symptomatic and asymptomatic health team ${ }^{(20)}$ also extended to their contacts ${ }^{(14,16,20)}$ and patients ${ }^{(11,16)}$. Contact screening was also presented as a protocol measure for testing for COVI-19(11). The importance of 
screening asymptomatic professionals is emphasized in order to mitigate the transmissibility of the disease ${ }^{(20)}$.

\section{Conducting targeted training}

In this category, the focus of studies on the attire and unattire training of professionals was found, carried out by different approach techniques, in order to achieve the teams' skill and safety. The role of a "dofficer" stands out, a figure created to conduct the checklist for donning and doffing attire and optimizing the reuse of masks, avoiding contamination ${ }^{(13)}$. Futhermore, hand hygiene training was discussed by the authors ${ }^{(19)}$.

Evidence has shown that the use of training with short videos of attire and unattire procedures was effective as a quick alternative to empower teams. The advantages of using videos include training for a large number of professionals, optimizing time and reducing the materials used for training, which represents cost-effectiveness and guarantees social distance ${ }^{(9)}$. It warns of the importance of testing the videos before use and providing feedback for possible corrections and adjustments ${ }^{(9)}$.

In the line of training, realistic simulation is highlighted as the main teaching method, with emphasis on on-site simulation, with standardized simulators to help recognize and correct active threats in the environment and the implementation of protocols $s^{(10,15)}$. After the development of training that addressed biosafety issues focused on COVID-19, there was an increase in knowledge and skill on the part of professionals ${ }^{(9-10,17)}$.

\section{DISCUSSION}

It appears that the approach to biosafety issues facing COVID-19 should not be restricted to the development of research and the development of academic discussions. That is, the effective use of recommendations on the use of PPE is necessary, the restructuring of new operational and clinical routines and flows in the practice of services, as well as the monitoring of healthcare professionals, especially testing, and training to enable teams to deal with highly infectious pathogens and disease outbreaks. In this context, it is worth mentioning the role of nurses, who are working not only in direct care for patients, but also in the management of services and in decision-making processes ${ }^{(21-22)}$.

As for PPE as essential items of biosafety, the studies in the sample associate the discussion with the elaboration of protocols and the execution of training. Thus, in view of these guidelines, technical characterizations appear that support the recommendations for use. Under COVID-19, the Center for Disease Control and Prevention (CDC) provides recommendations for standard precautions and high-risk exposure. Standard precautions are infection prevention and control practices that should be adopted in the care of all patients, suspected or confirmed, in addition to the use of PPE, in order to protect healthcare professionals and minimize the spread of infections ${ }^{(23)}$. On the other hand, high-risk exposure is related to direct patient care, such as physical examination, performing aerosol generation procedures, contact with infectious secretions without the use of PPE or non-hand hygiene after these procedures ${ }^{(24)}$.

Regarding the procedures that generate aerosols, the indicated PPE, due to the high transmissibility, are respirators N95, PFF2,
PFF3, N99 or N100 (with manufacturer's guarantee for a minimum efficiency of $98 \%$ of filtration of particles up to $0.3 \mu^{(25)}$ and bacteriological filtration efficiency greater than $95 \%)^{(26)}$, glasses or face shields, protective clothing with long sleeves, scrub caps/ coat (clothing that is resistant to tears, punctures and fluids) and gloves. Thus, the ideal is the use of all these PPE in health services $^{(27)}$. However, the evidence of this ILR ${ }^{(12-13,16,18)}$ shows the choice of using the full attire, highlighting the use of respirators to attend to suspected or confirmed cases of COVID-19, regardless of exposure being of high risk or not.

High risk contamination cases, resulting from the aerosolization phenomenon, induce reflection on the exposure of body areas not protected by PPE. Thus, in the sample, contamination of the neck and ear is discussed, since the recommended PPE does not cover such areas. In this sense, a study carried out in Israel, in the emergency department, in March 2020, verified the contamination of the neck and ear of professionals who participated in a realistic simulation of care for patients with COVID-19 ${ }^{(28)}$. Therefore, it is proposed to discuss the use of PPE capable of also covering these body areas, such as balaclava. In the meantime, it is worth mentioning that WHO, in 2020, reported that aprons should be prioritized instead of overalls for the treatment of patients with COVID-19 (29); however, during the pandemic, difficulties were observed in the use of overalls ${ }^{(17)}$, with a possible contamination in the unattire process ${ }^{(30)}$, opting for other PPE to protect healthcare professionals in uncovered areas potentially contaminable.

Regarding the supply of PPE, demand that involves management in the purchase of health supplies, is conditioned to unrestricted availability, as well as its quality. For a better control of this demand, a study carried out in Italy dealt with the creation of a central storage structure and distribution of kits assembled in accordance with WHO recommendations ${ }^{(27)}$. The apron fragility was revealed in the study, although the material for making this PPE has not yet been explained. The recommendations indicate that the aprons must be resistant to the penetration of fluids carried by the air (fluid repellency), have a minimum weight of $50 \mathrm{~g} / \mathrm{m} 2$ and bacteriological filtration efficiency $>99 \%{ }^{(26)}$, characterizing the impermeability that is a PPE requirement to be used in COVID-19.

In spite of this, it is essential to obtain PPE to face the daily pandemic, variables such as: sufficient manufacture of PPE and resources for its acquisition are currently overlapping, thus, health service managers question themselves and seek scientific evidence that sustain the reuse of some of these PPE, namely respirators, such as the N95, in particular their time of reuse and validity ${ }^{(31)}$. Therefore, bodies such as the National Institute for Occupational Safety and Health (NIOSH) have endorsed quantitative testing in the processing of these PPE. The tests seek to determine the number of times a respirator can be reused, considering as a priority to maintain the ideal seal for the mouth and nose region $^{(32)}$. Still, they are considered to be processed through sterilization strategies ${ }^{(33-35)}$. This scarcity has induced health services to guide professionals to maintain respirators in places without humidity, packed in paper envelopes, as a possibility, and it has been suggested not to clean and disinfect them for later reuse, because when wet they lose their filtration capacity ${ }^{(4)}$. Other PPE with potential for reuse are goggles and face shield. For these, 
the reuse mechanism is already established, as they are viable for cleaning and decontamination with sanitizing products in accordance with the institutional rules of each health service ${ }^{(36)}$.

With regard to the restructuring of services, with the establishment of new flows and routines aimed at the current pandemic situation and the protection of healthcare professionals and other patients, adjustments aimed at structural improvements were evidenced, in order to segregate patients with suspicion or confirmation of SARS-CoV-2 infection in specific areas of the hospital unit, readjusted for this purpose. In this sense, cohort wards were created for symptomatic cases, but without epidemiological risk ${ }^{(12)}$, and isolation wards and ICU beds for suspected/ confirmed cases ${ }^{(12,15,19)}$. These new structures had in common the social isolation between patients, guaranteed by the distance between the beds and the creation of divisions between the beds ${ }^{(12,19)}$, in addition to air flow systems with controlled direction, with constant changes and differential negative pressure ${ }^{(12,15,19)}$.

In this context, the dispersive difference between aerosols and droplets stands out, since aerosolized particles have high dispersion power. Thus, the phenomenon of aerosolization is a relevant condition in a patient with COVID-19 hospitalized in ICU environments. Therefore, $\mathrm{WHO}^{(37)}$ recommends that $\mathrm{ICU}$ rooms have negative pressure with a minimum of 12 air changes per hour or at least $160 \mathrm{~L} /$ second/patient in facilities with natural ventilation. This recommendation matches the structured practice in studies of the sample. In the ICU, airborne transmission may be possible in procedures that generate aerosols such as those performed in endotracheal intubation, bronchoscopy, aspiration, administration of nebulizer treatment, manual ventilation before intubation, disconnecting patients from the ventilator, noninvasive positive pressure ventilation, tracheostomy, cardiopulmonary resuscitation placing patients in a prone position ${ }^{(37)}$.

Considering that SARSCoV-2 can remain in the air and on surfaces for several hours and several days, hand hygiene measures, the use of negative pressure ventilation in critical sectors and the disinfection of frequently touched surfaces are necessary to reduce the spread of the new coronavirus through the aerosol ${ }^{(38)}$. The intensification of cleaning and disinfection of the environment and medical and hospital equipment, with disinfectants such as sodium hypochlorite ${ }^{(11)}$ or based on active chlorine ${ }^{(19)}$, is a measure of biosafety, pointed out by studies ${ }^{(11,19)}$. Sodium hypochlorite at a concentration of $0.1 \%$ can reduce contamination by coronavirus on surfaces within one minute of exposure ${ }^{(38)}$.

The mobilization in the reorganization of services to meet the new demand is related to the elaboration of checklists and clinical and operational protocols. In this sense, a study carried out in a municipality in southern Brazil highlighted the role of nurses in the creation of new flows and routines, as well as in other issues related to hospital management, demonstrating that they are qualified professionals to work in the care and management of units ${ }^{(22)}$.

The clinical monitoring of healthcare professionals, especially doctors and nurses who work in hospital care, implies ensuring adequate biosafety measures and the removal of symptomatic employees, or who are part of the risk group, through screening and testing due the high lethality observed. Thus, the four studies of this ILR that portrayed the theme ${ }^{(11,14,16,20)}$ reported information from employees from the collection of swabs in the nose, throat and oropharynx, collection of blood and serum samples for antibodies of specific IgM and IgG for SARS-CoV-2, molecular testing of real-time reverse transcriptase polymerase chain reaction (RT-PCR) for the virus in symptomatic and asymptomatic groups, and presence of mild symptoms (cough, fever or sore throat or common cold) with or without a known epidemiological link for exposure to SARS-CoV-2 (travel to high-risk areas and close contact with the confirmed case). Additionally, the surveillance of healthcare professionals exposed by COVID-19 was indicated, by means of telephone contact, in order to monitor the symptoms and measure the temperature over a period of 14 days using a digital infrared thermometer ${ }^{(11,16)}$.

Scholars suggest that knowing the infection's status quo may assist in mitigating the transmissibility of the virus in the intra and extra-hospital environments, as well as in the adoption of measures to prevent nosocomial infection, based on the testing algorithms of both healthcare professionals and patients ${ }^{(12,16)}$. Screenability, through testing healthcare professionals, whether through RT-PCR, serology and rapid tests, is the ideal method to learn about the epidemiological profile of COVID-19 and, therefore, adopt preventive measures for these professionals, family members, friends and patients ${ }^{(11,16)}$.

RT-PCR, the gold standard in the diagnosis of COVID-19, is indicated to check the RNA of SARS-CoV-2 molecule in the acute phase, between the third and the seventh day of the onset of symptoms, from the sample collection in the nasopharynx. It should be noted that, after the tenth day, the amount of RNA tends to decrease. In cases of viral genetic inactivation, the molecular test can be detectable for two to six weeks, not indicating a relevance in the transmissibility of the disease ${ }^{(39-40)}$. Therefore, it is important to identify, at an early stage, virus activation, so that conduct of isolation or removal of healthcare professionals and hospitalizations in severe cases is carried out adequately by the services and health ${ }^{(41-42)}$

With regard to immunochromatographic tests (rapid tests for $\lg \mathrm{M} / \lg \mathrm{G}$ ) and serological tests (lgM, $\lg \mathrm{A}$ and $\lg \mathrm{G}$ antibodies), they can assist in the mapping of healthcare professionals who have already had COVID-19 or have been exposed to the virus in some way; however, it is noteworthy that they have no diagnostic function $^{(42)}$. Positive tests for IgM or IgA represent an acute infection, whereas positive lgG tests indicate previous contact with the virus, conferring possible immunity; however, it is not known, until now, if the infection confers neutralizing and lasting immunity ${ }^{(39)}$.

In Brazil, some recommendations are outlined to guide health services or companies in carrying out tests for COVID-19, namely: detecting early cases with the realization of RT-PCR, as the active phase is evident in which individuals are transmitting the virus; serological tests/rapid tests are not recommended for the early detection of cases, as they indicate past disease; professionals on leave due to suspicion or confirmation by COVID-19 must sign the document on the fulfillment of their home isolation; RT-PCR tests must be performed in laboratories certified by the Central Public Health Laboratories (LACEN - Laboratórios Centrais de Saúde Pública) ${ }^{(43)}$.

An important factor in the transmissibility of COVID-19 is the high viral load in the upper respiratory tract, even among 
pre-symptomatic patients. This fact agrees with a study that reported the virus positivity in groups stratified as asymptomatic, with no clinical suspicion of the disease at the time of collecting nose and throat swabs ${ }^{(20)}$. In addition, screening based on clinical symptoms alone does not allow diagnosing individuals with infection, nor does it control the transmission of COVID-19. Screening and testing asymptomatic and symptomatic groups makes it possible to take measures to contain the virus, such as removal of infected healthcare professionals and blocking admissions to wards ${ }^{(20,44)}$.

Screening approaches focused only on symptomatic healthcare professionals are inadequate to suppress nosocomial spread. Studies suggest that mass screening and isolation of asymptomatic individuals should be carried out to interrupt the transmission chain of coronavirus. It is recommended to carry out weekly tests in asymptomatic patients to mitigate viral spread, since a progressive reduction in the transmission of SARS-CoV-2 from 16 to $23 \%$ was observed, when the results of the tests performed were available within 24 hours ${ }^{(45)}$.

Another strategy employed by the health services, with a view to protecting the health and support teams, was the provision of systematic training, which is one of the main points of discussion among organizations such as $\mathrm{WHO}^{(37)}, \mathrm{CDC}^{(46)}$ and $\mathrm{ANVISA}^{(4)}$. Despite the mandatory findings on the structuring of training, whether prior or during the outbreak, new demands for training may arise due to the lack of pathophysiological knowledge that still permeate this pandemic. Therefore, proactivity, secondary to training processes, should be encouraged, encouraging service managers to develop and update checklists, protocols, advance warnings, available daily in health services with professionals, certifying the reach of information.

The evidence of this ILR with regard to the structuring of training for preventing COVID-19 in healthcare professionals shows that, among the topics addressed, PPE attire and unattire stands out ${ }^{(9-}$ ${ }^{10,17)}$. In this sense, effective training can improve the individual skills of professionals, mitigating contamination of these workers by COVID-19. Studies of this ILR showed a significant improvement in professionals' knowledge and skills after the educational interventions carried out ${ }^{(9-10,17)}$. This fact is corroborated in the literature, which shows that attiring and unattiring repeatedly enables the development of the necessary skill to handle PPE, including to learn about how to deal with the physical restrictions imposed by them ${ }^{(27)}$. Added to the development of unconditionally safe skills to the attire and unattire procedures, meticulous hand hygiene throughout the process, with emphasis on the fact that in PPE doffing, hand hygiene must be performed item by item ${ }^{(4)}$.

The interest in training for the use of PPE resulted in the creation of a function within the staff of healthcare professionals in the hospital, described in one of the sample studies, called "dofficer", which is configured in the role of monitoring and supervision at the stage attire and unattire procedures. Through this monitoring, it is possible to detect flaws in the process, allowing, in real time, its correction and identification of weak points that, eventually, are repeated in the process in question for the production of new capabilities ${ }^{(13)}$.

The evidence that focused on training aimed at assisting patients (simulated) with COVID-19 provided a list of active failures by healthcare professionals and latent risks to which they were exposed, in addition to showing high levels of anxiety due to the lack of previous training and familiarity with the situation ${ }^{(15)}$. Other topics covered in the training were hand hygiene ${ }^{(17)}$, disposal of hospital waste ${ }^{(17)}$ and carrying out high-risk contamination procedures $^{(15)}$. Considering COVID-19 person-to-person transmission through contaminated droplets, hands and surfaces, transmission chain interruption can be reduced by frequent hand hygiene with soap and water or an alcohol-based disinfectant, this practice should be encouraged and incorporated into organizational training.

In relation to the teaching methods used in training, the gain obtained with the structuring of educational interventions based on simulation and educational videos stands out, which proved to be effective in improving professional knowledge and skills. It can be pointed out as a differential the clinical simulation in situ (in the professionals' own work environment), allied to the use of high-fidelity mannequins, seeking to make the setting as realistic as possible for professionals. In this type of training, in addition to assessing knowledge and skills, it is possible to detect other points around teamwork and communication, such as identifying unsafe acts practiced by professionals and risks present in the work environment, contributing to reduce anxiety and increase team trust and preparation ${ }^{(15)}$.

Regarding the use of educational videos, although this technology does not allow professionals to be immersed in situations that replicate reality, is effective in terms of time and resources to carry out the simultaneous training of many participants. In response to the current pandemic situation of COVID-19, video training for the development of technical skills such as donning and doffing PPE, as opposed to simulation training, can provide a means of training a large number of personnel, at the same time that minimizes the amount of time and PPE used in training, ensuring social distance ${ }^{(9)}$.

\section{Study limitations}

The lack of previous research on the topic addressed can be pointed out as a limitation of this study. In this regard, even though the main national and international databases have been rigorously consulted, the theme is current, which may show that identifying such a limitation must also point to new demands for investigations.

\section{Contributions to nursing, health, and public policies}

The debate developed in this ILR provides important subsidies for the performance of nurses and hospital service managers, considering the risk management related to the assistance provided by healthcare professionals in the COVID-19 setting. Thus, it brings contributions to the performance of these actors in the political and social sphere, in the discussions and deliberations of preventive measures and diagnoses for the disease; in the managerial dimension, with regard to the acquisition, quality, quantity and conservation of PPE and the development of new protocols, flows and routines. It also contributes to the implementation of proven effective strategies for continuing education aimed at tackling the pandemic. 


\section{FINAL CONSIDERATIONS}

Analyzing the scientific evidence about the main biosafety measures for preventing COVID-19 in healthcare professionals made it possible to trigger an important discussion about PPE from the perspective of the transmissibility of SARS-CoV-2. In the sample found in this ILR, the authors were able to corroborate that biosafety measures should consider the effective use of recommendations about the use of PPE, the restructuring of new operational and clinical routines and flows in the practice of services, the monitoring of healthcare professionals by comprehensive screening and traceability, and the systematic use of training to enable teams to deal with highly infectious pathogens and disease outbreak situations.

The new training demands are demanding emerging adjustments and updates from professionals, according to the perspective of SARSCoV-2 transmissibility, considering the recognition of PPE material quality and the possible auditory and visual restrictions, as well as the uncomfortable condition caused by them. Still, the evidence indicates the importance of a previous structural study of the units that will receive patients with COVID-19, considering, among others, the latent risks, equipment failures, electrical problems, lack of materials and supplies, flow of passage and inadequate transport. Hence, it is expected, before the COVID-19 pandemic, that health services can carry out structural changes and systematic training, in order to diagnose specific situations in this new health care model.

\section{FUNDING}

This work was carried out with the support of the Academic Excellence Program for the Coordination for the Improvement of Higher Education Personnel (Programa de Excelência Acadêmica da Coordenação de Aperfeiçoamento de Pessoal de Nível Superior - PROEX/CAPES).

\section{REFERENCES}

1. World Health Organization (WHO). WHO COVID-19 preparedness and response progress report [Internet]. 2020 [cited 2020 Sep 10]. Available from: https://www.who.int/publications/m/item/who-covid-19-preparedness-and-response-progress-report---1-february-to-30-june-2020

2. Holland M, Zaloga DJ, Friderici CS. COVID-19 Personal Protective Equipment (PPE) for the emergency physician. Vis J Emerg Med. 2020;19:100740. https://doi.org/10.1016/j.visj.2020.100740

3. Centers for Disease Control and Prevention (CDC). Interim U.S. guidance for risk assessment and public health management of healthcare personnel with potential exposure in a healthcare setting to patients with Coronavirus Disease (COVID-19) [Internet]. 2020 [cited 2020 Aug 18]. Available from: https://www.cdc.gov/coronavirus/2019-ncov/hcp/guidance-risk-assesment-hcp.html

4. Agência Nacional de Vigilância Sanitária (Anvisa). Gerência de Vigilância e Monitoramento em Serviços de Saúde. Gerência Geral de Tecnologia em Serviços de Saúde. Nota Técnica no 04/2020. Orientações para serviços de saúde: medidas de prevenção e controle que devem ser adotadas durante a assistência aos casos suspeitos ou confirmados de infecção pelo novo coronavírus (SARS-CoV-2) [Internet]. 2020 [cited 2020 Apr 08]. Available from: http://portal.anvisa.gov.br/documents/33852/271858/Nota+T\%C3\%A9cnica+n+04-2020+GVIMS-GGTES-ANVISA/ ab598660-3de4-4f14-8e6f-b9341c196b28

5. Teixeira CFZ, Soares CM, Souza EA, Lisboa ES, Pinto ICM, Andrade LR, et al. The health of healthcare professionals coping with the Covid-19 pandemic. Ciênc Saúde Colet. 2020;25(9):3465-74. https://doi.org/10.1590/1413-81232020259.19562020

6. Whittemore R, Knafl K. The integrative review: updated methodology. J Adv Nurs. 2005;52(5):546-53. https://doi.org/10.1111/j.1365-2648.2005.03621.x

7. Moher D, Liberati A, Tetzlaff J, Altman DG, The PRISMA Group (2009). Preferred Reporting Items for Systematic Reviews and Meta-Analyses: The PRISMA Statement. PLoSMed. 6(7):e1000097. https://doi.org/10.1371/journal.pmed1000097

8. Lockwood C, Porrit K, Munn Z, Rittenmeyer L, Salmond S, Bjerrum M, et al. Capítulo 2: Revisões sistemáticas de evidências qualitativas. In: Aromataris E, Munn Z (Eds). Manual da JBI para síntese de evidências. JBI [Internet]. 2020 [cited 2020 Apr 13]. Available from: https:// synthesismanual.jbi.global

9. Christensen L, Rasmussen CS, Benfield T, Franc JM. A randomized trial of instructor-led training versus video lesson in training health care providers in proper donning and doffing of personal protective equipment. Disaster Med Public Health Prep. 2020;14(4):514-20. https://doi. org/10.1017/dmp.2020.56

10. Díaz-Guio DA, Ricardo-Zapata A, Ospina-Velez J, Gómes-Candamil G, Mora-Martinez S, Rodriguez-Morales A. Cognitive load and performance of health care professionals in donning and doffing PPE before and after a simulation-based educational intervention and its implications during the COVID-19 pandemic for biosafety. Infez Med [Internet]. 2020 [cited 2020 Apr 13];28(suppl 1):111-7. Available from: https://pubmed.ncbi.nlm.nih.gov/32532947/

11. Wee LE, Fua TP, Chua YY, Ho AFW, Sim XYJ, Conceicao EP, et al. Containing COVID-19 in the emergency department: the role of improved case detection and segregation of suspect cases. Acad Emerg Med. 2020;27(5):379-87. https://doi.org/10.1111/acem.13984

12. Wee LE, Sim XYJ, Conceicao EP, Tan BH, Venkatachalam I, Ling ML. Containing COVID-19 outside the isolation ward: the impact of an infection control bundle on environmental contamination and transmission in a cohorted general Ward. AJIC. 2020;48(9):1056-61. https:// doi.org/10.1016/j.ajic.2020.06.188

13. Evans HL, Thomas CS, Bell LH, Hink AB, O'Driscoll S, Tobin CT, et al. Development of a sterile personal protective equipment donning and doffing procedure to protect surgical teams from SARS-CoV-2 Exposure during the COVID-19 Pandemic. Surg Infect. 2020;21(8):671-6. https://doi.org/10.1089/sur.2020.140 
14. Reusken $\mathrm{CB}$, Buiting A, Bleeker-Rovers $\mathrm{C}$, Diederen $\mathrm{B}$, Hooiveld $\mathrm{M}$, Friesema $\mathrm{H}$, et al. Rapid assessment of regional SARS-CoV-2 community transmission through a convenience sample of healthcare workers, the Netherlands, March 2020. Euro Surveill. 2020;25(12):2000334. https://doi.org/10.2807/1560-7917.ES.2020.25.12.2000334

15. Fregene TE, Nadarajah P, Buckley JF, Bigham S, Nangalia V. Use of in situ simulation to evaluate the operational readiness of a highconsequence infectious disease intensive care unit. Anaesthesia. 2020;76(6):733-8. https://doi.org/10.1111/anae.15048

16. Min L, Shou-Zhen C, Ke-Wei X, Yang Y, Qing-Tang Z, Hui Z, et al. Use of personal protective equipment against coronavirus disease 2019 by healthcare professionals in Wuhan, China: cross sectional study. BMJ. 2020;369:2195. https://doi.org/10.1136/bmj.m2195

17. Tan W, Ye Y, Yang Y, Chen Z, Yang X, Zhu C, et al. Whole-Process emergency training of personal protective equipment helps healthcare workers against COVID-19 Design and Effect. J Occup Environ Med;62(6):420-3. https://doi.org/10.1097/JOM.0000000000001877

18. Jin YH, Huang $Q$, Wang YY, Zeng XT, Luo LS, Pan ZY. Perceived infection transmission routes, infection control practices, psychosocial changes, and management of COVID-19 infected healthcare workers in a tertiary acute care hospital in Wuhan: a crosssectional survey. Mil Med Res. 2020;7(1):24. https://doi.org/10.1186/s40779-020-00254-8

19. Razzini K, Castrica M, Menchetti L, Maggi L, Negroni L, Orfeo NV, et al. SARS-CoV-2 RNA detection in the air and on surfaces in the COVID-19 ward of a hospital in Milan, Italy. Science Total Environ. 2020;742:e140540. https://doi.org/10.1016/j.scitotenv.2020.140540

20. Rivett L, Sridhar S, Sparkes D, Routledge M, Jones NK, Forrest S, et al. Screening of healthcare workers for SARS-CoV-2 highlights the role of asymptomatic carriage in COVID-19 transmission. Elife. 2020;11(9):e58728. https://doi.org/10.7554/eLife.58728

21. Bitencourt JVOV, Meschial WC, Frizon G, Biffi P, Souza JB, Maestri E. Nurse's protagonism in structuring and managing a specific unit for COVID-19. Texto Contexto Enferm. 2020;29:e20200213. https://doi.org/10.1590/1980-265x-tce-2020-0213

22. Siegel JD, Rhinehart E, Jackson $M$, Chiarello L, and the Healthcare Infection Control Practices Advisory Committee. 2007. Guideline for Isolation Precautions: Preventing Transmission of Infectious Agents in Healthcare Settings[Internet]. 2020 [cited 2020 Apr 08]. Available from: http://www.cdc.gov/ncidod/dhqp/pdf/isolation2007.pdf

23. Centers for Disease Control and Prevention (CDC). Interim Operational Considerations for Public Health Management of Healthcare Workers Exposed to or Infected with COVID-19: non-US Healthcare Settings[Internet]. 2020 [cited 2020 Apr 15]. Available from: https://www.cdc. gov/coronavirus/2019-ncov/hcp/non-us-settings/public-health-management-hcwexposed.html

24. Agência Nacional de Vigilância Sanitária (Anvisa). Nota Técnica n05/2020. Orientações para a prevenção e controle de infecções pelo novo coronavírus (SARS-COV-2) em instituições de longa permanência para idosos (ILPI)[Internet]. 2020 [cited 2020 Apr 28]. Available from: https://www20.anvisa.gov.br/segurancadopaciente/index.php/alertas/item/ nota-tecnica-n-05-2020- gvims-ggtes-anvisa-orientacoes-para-a-prevencao-e-o-controle-de-infeccoes-pelo-novo-coronavirussars-cov-2-ilpi

25. Ministério da Saúde (BR). RDC n 356, de 23 de março de 2020. Dispõe, de forma extraordinária e temporária, sobre os requisitos para a fabricação, importação e aquisição de dispositivos médicos identificados como prioritários para uso em serviços de saúde, em virtude da emergência de saúde pública internacional relacionada ao SARS-CoV-2 [Internet]. 2020 [cited 2020 Apr 28]. Available from: http://portal. anvisa.gov.br/documents/10181/5809525/RDC_356_2020_COMP.pdf/fbe549f1-b74c42e9-9979-2ab98cf55de2

26. Sorbello M, El-Boghdadly K, Di Giacinto I, Cataldo R, Esposito C, Falcetta S, etal. The Italian coronavirus disease 2019 outbreak: recommendations from clinical practice. Anaesthesia. 2020;75(6):724-32. https://doi.org/10.1111/anae.15049

27. Feldman O, Meir M, Shavit D. Exposure to a surrogate measure of contamination from simulated patients by emergency department personnel wearing personal protective equipment. JAMA. 2020;323(20):2091-3. https://doi.org/10.1001/jama.2020.6633

28. World Health Organization (WHO). Laboratory testing for coronavirus disease 2019 (COVID-19) in suspected human cases [Internet]. 2020 [cited 2020 Apr 20]. Available from: https://www.cdc.gov/coronavirus/2019-ncov/downloads/A_FS_HCP_COVID19_PPE.pdf

29. World Health Organization (WHO). Rational use of personal protective equipment for coronavirus disease (COVID-19): interim guidance [Internet]. 2020 [cited 2021 Apr 20]. Available from: https://apps.who.int/iris/bitstream/handle/10665/331215/WHO-2019-nCov-IPCPPE_ use-20201-eng.pdf

30. Verbeek JH, Rajamaki B, ljaz S, Sauni R, Toomey E, Blackwood B, et al. Personal protective equipment for preventing highly infectious diseases due to exposure to contaminated body fluids in healthcare staff. Cochrane Database Syst Rev. 2020;4:(CD011621). https://doi. org/10.1002/14651858.CD011621.pub4

31. Garcia GPA, Fracarolli IFL, Santos HEC, Souza VRS, Cenzi CM, Marziale MHP. Utilização de equipamentos de proteção individual para atendimento de pacientes com covid-19: revisão de escopo. Rev Gaúcha Enferm [Internet]. 2021 [cited 2021 Apr 20];42(esp):e20200150. Available from: https://seer.ufrgs.br/RevistaGauchadeEnfermagem/article/view/110766

32. Moschella P, Liao W, Litwin A, Foulk J, Anthony J, Player M, et al. Repeated vaporised hydrogen peroxide disinfection of $3 \mathrm{M} 1860$ N95 mask respirators does not degrade quantitative fit performance. Br J Anaesth. 2021; 126(3):125-127. https://doi.org/10.1016/j.bja.2020.12.021

33. Anderegg L, Meisenhelder C, Ngooi CO, Liao L, Xiao W, Chu S, et al. A scalable method of applying heat and humidity for decontamination of N95 respirators during the COVID-19 crisis. PLoS One. 2020;15(7):e0234851. https://doi.org/10.1371/journal.pone.0234851

34. Cramer A, Tian E, Yu SH, Galanek M, Lamere E, Li J, et al. Assessment of the qualitative fit test and quantitative single-pass filtration efficiency of disposable N95 masks following gamma irradiation. JAMA Netw Open. 2020;3(5):e209961. https://doi.org/10.1001/jamanetworkopen.2020.9961

35. Kumar A, Kasloff SB, Leung A, Cutts T, Strong JE, Hills K, et al. N95 mask decontamination using standard hospital sterilization technologies. MedRxiv 2020. https://doi.org/10.1101/2020.04.05.20049346 
36. Conselho Federal de Enfermagem (COFEN). Recomendações gerais para organização dos serviços de saúde e preparo das equipes de enfermagem: versão 2[Internet]. 2020 [cited 2020 Apr 20]. Available from: http://www.cofen.gov.br/wp-content/uploads/2020/04/cofen_ covid-19_cartilha_v3-4.pdf

37. Fathizadeh H, Maroufi P, Momen-Heravi M, Dao S, Köse S, Ganbarov K, et al. Protection and disinfection policies against SARS-CoV-2 (COVID-19). Infez Med [Internet]. 2020 [cited 2020 Mar 13];28(2):185-91.Available from: https://pubmed.ncbi.nlm.nih.gov/32275260/

38. Kampf G, Todt D, Pfaender S, Steinmann E. Persistence of coronaviruses on inanimate surfaces and its inactivation with biocidal agents. J Hospit Infect. 2020;104(3):246-51. https://doi.org/10.1016/j.jhin.2020.01.022

39. Medeiros EAS. Health professionals fight against COVID-19. Acta Paul Enferm. 2020;33(11):1-4. https://doi.org/10.37689/ acta-ape/2020EDT0003

40. Ministério da Saúde (BR). Recomendações de proteção aos trabalhadores dos serviços de saúde no atendimento de COVID-19 e outras síndromes gripais [Internet]. 2020[cited 2020 Sep 4]. Available from: http://renastonline.ensp.fiocruz.br/recursos/ recomendacoes-protecao-aos-trabalhadores-servicos-saude-atendimento-covid-19-outras

41. Agência Nacional de Vigilância Sanitária (Anvisa). Orientações para serviços de saúde: medidas de prevenção e controle que devem ser adotadas durante a assistência aos casos suspeitos ou confirmados de infecção pelo novo coronavírus (SARS-CoV-) [Internet]. 2020 [cited 2020 Sep 4]. Available from: http://portal.anvisa.gov.br/documents/33852/271858/Nota+T\%C3\%A9cnica+n+04-2020+GVIMS-GGTES-ANVISA/ ab598660-3de4-4f14-8e6f-b9341c196b28

42. Agência Nacional de Vigilância Sanitária (Anvisa). Testes para Covid-19: perguntas e respostas. [Internet]. Brasília: Agência Nacional de Vigilância Sanitária; 2020 [cited 2020 Sep 04]. Available from: http://portal.anvisa.gov.br/documents/219201/4340788/ Perguntas+e+respostas+-+testes+para+Covid-19.pdf/9fe182c3-859b-475f-ac9f-7d2a758e48e7

43. Ministério da Saúde (BR). Orientações para prevenção e vigilância epidemiológica das infecções por SARS-CoV-2 (COVID-19) dentro dos serviços de saúde [Internet]. Brasília: Ministério da Saúde. 2020. [cited 2020 Sep 03]. Availablefrom: http://portal.anvisa.gov.br/ documents/33852/271858/NOTA+T\%C3\%89CNICA+-GIMS-GGTES-ANVISA+N\%C2\%BA+07-2020/f487f506-1eba-451f-bccd-06b8f1b0fed6

44. Arons MM, Hatfield KM, Reddy SC, Kimball A, James A, Jacobs JR, et al. Presymptomatic SARS-CoV-2 infections and transmission in a skilled nursing facility. N Engl J Med. 2020;382(22):2081-90. https://doi.org/0.1056/NEJMoa2008457

45. Grassly NC, Pons-Salort M, Parker EPK, White PJ, Ferguson NM. Comparison of molecular testing strategies for COVID-19 control: a mathematical modelling study. Lancet Infect Dis 2020;20:1381-89. https://doi.org/10.1016/ S1473-3099(20)30630-7

46. Centers for Disease Control and Prevention (CDC). Use personal protective equipment (PPE) when caring for patients with confirmed or suspected COVID-19 [Internet]. 2020 [cited 2020 Apr 20]. Available from: https://www.cdc.gov/coronavirus/2019-ncov/downloads/A_FS_ HCP_COVID19_PPE.pdf 